\title{
Citations in Stone: The Material World of Hogbacks
}

\author{
Howard Williams
}

Williams, H. 2016. Viking mortuary citations, European Journal of Archaeology 19(3): 400-14. http://dx.doi.org/10.1080/14619571.2016.1186882

\begin{abstract}
This article explores a meshwork of citations to other material cultures and architectures created by the form and ornament of house-shaped early medieval recumbent stone monuments popularly known in Britain as 'hogbacks'. In addition to citing the form and ornament of contemporary buildings, shrines, and tombs, this article suggests recumbent mortuary monuments referenced a far broader range of contemporary portable artefacts and architectures. The approach takes attention away from identifying any single source of origin for hogbacks. Instead, considering multi-scalar and multi-media references within the form and ornament of different carved stones provides the basis for revisiting their inherent variability and their commemorative efficacy by creating the sense of an inhabited mortuary space in which the dead are in dialogue with the living. By alluding to an entangled material world spanning Norse and Insular, ecclesiastical and secular spheres, hogbacks were versatile technologies of mortuary remembrance in the Viking Age.
\end{abstract}

Keywords: British Isles, Viking Age, early medieval, hogbacks, commemoration, memory, citation, meshwork

\section{Introduction}

Dating broadly to the tenth-eleventh century on stylistic grounds, recumbent stone monuments popularly known as hogbacks have long been familiar to early medieval researchers as 'Viking colonial monuments' (Collingwood, 1927; Lang, 1972-74; 1984; see also Hall, 2015; Williams, 2015). They are found in northern England (particularly North Yorkshire and Cumbria) and southern Scotland (with a focus around the Clyde and Forth) with scattered examples surviving elsewhere across the British Isles. These stones are often described as 'house-shaped'; some stones display bowed ridge-lines and some have convex sides. They are diverse in their size, shape, end-beasts, and ornament, but most are around $1.5 \mathrm{~m}$ in length. While there remain disputes regarding which recumbent stone monuments might be termed 'hogbacks', around 120 are currently referred to as 'hogbacks' or hogbackrelated monuments (Lang, 1972-74; 1984; see also Cramp, 1984a). Hogbacks are best known to academic and popular literature from the largest collections found, notably those from Govan (Glasgow; Lang, 1972-74: 224-27; 1994), Gosforth (Cumbria; Bailey \& Cramp, 1988: 105-8), Brompton (North Yorks.; Lang, 2001: 74-79) (Figure 1), Lythe (North Yorks.; Lang, 2001: 159-66), and Sockburn (Co. Durham; Cramp, 1984b: 140-44).

Interpreting these monuments has proved problematic for scholars on many grounds. While other early medieval recumbent stone monuments have been recovered situated over graves (including a 'hogback' from Winchester), in northern Britain no hogbacks have been recorded as having been discovered in situ. Furthermore, many monuments survive only as broken fragments and their original contexts of use (including associations with other stones) are irrecoverable. While usually considered to be grave covers, the variability 
of hogbacks is a challenge for their interpretation: the subtypes are very different from each other. For example, some stones have large end-beasts (most often resembling bears), others have diminutive end-beasts (which could be ursine or dragonesque), while further examples display none at all. Their shape and side decoration vary considerably too. Monument subtypes also have overlapping distributions and different subtypes appear together at the same locations, making both the identification of regional types and the relative dates of monuments challenging. Unsurprisingly, given this host of factors, while they are usually regarded as 'tenth century', the duration of making and using hogbacks, and their precise functions, remains unclear (see Williams, 2015). There also remain questions regarding why some places have these recumbent stones, whereas neighbouring ecclesiastical sites, while producing tenth-eleventh-century sculpture and other archaeological evidence, might not produce any.

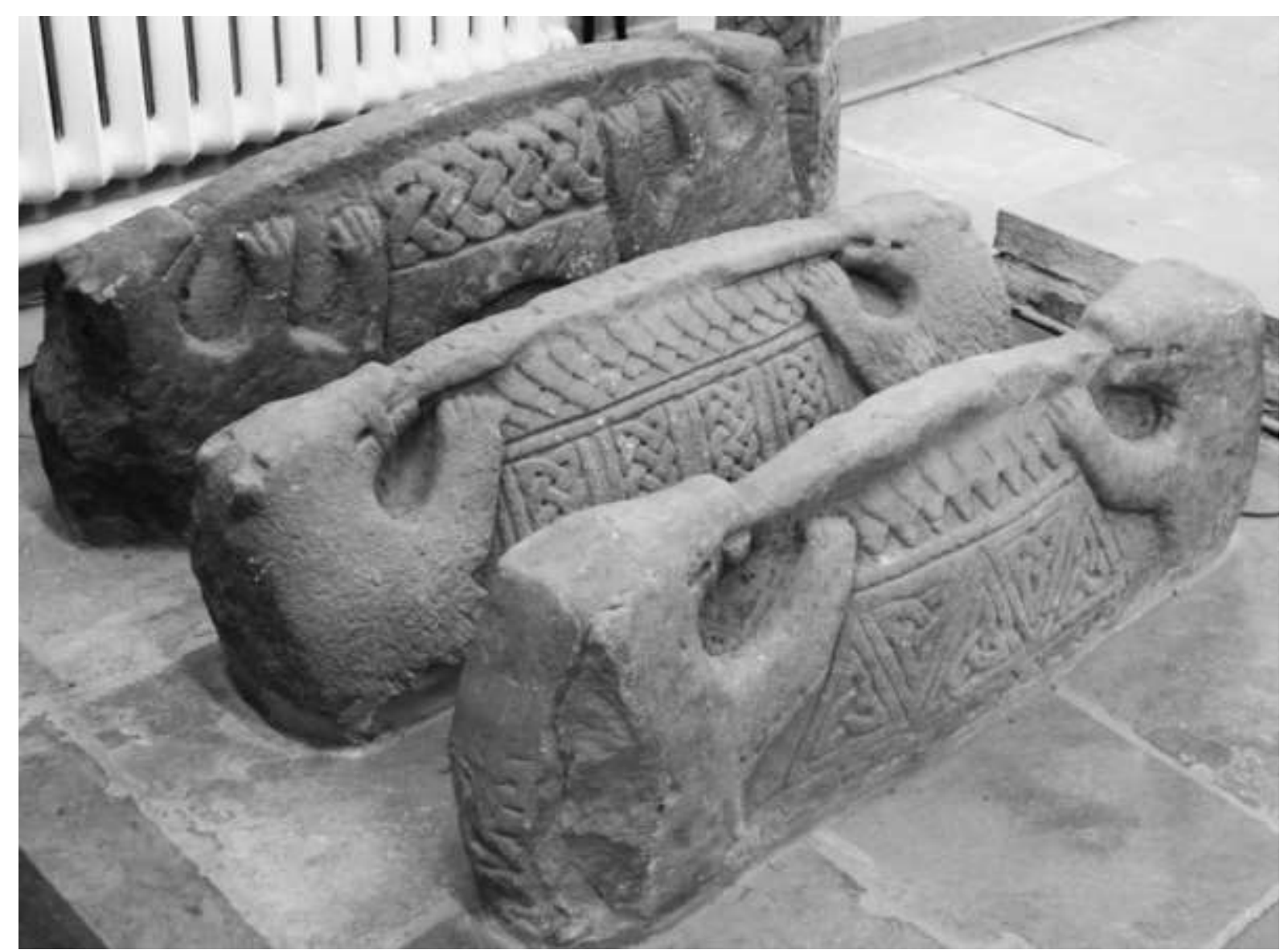

Figure 1. Hogbacks at Brompton (North Yorkshire), from left to right, types a (Brompton 17 and 19) and c (Brompton 20). Photograph by Howard Williams.

Despite this variability and interpretive complexity, hogbacks have been tenaciously tied together by scholars as a coherent category demanding a single context of use as Viking 'colonial' creations. However, there are no precursors in Scandinavia and a diverse range of possible antecedents within the British Isles (Lang, 1972-74; 1984; Bailey, 1980; Stocker, 2000; Kopár, 2012). Despite this lack of immediate and direct precedents, Lang regarded their distribution and character as 'Hiberno-Norse', despite their near-absence in Ireland and Wales, absence from the Isle of Man and rarity in Cheshire, Lancashire, and south-west 
Scotland: all areas of Norse settlement and influence. Furthermore, they are frequently considered to represent evidence of religious syncretism, or at least drawing upon preChristian secular stories, because some depict scenes identified as belonging to Norse mythology while the stones themselves were most probably carved and displayed in Christian ecclesiastical mortuary environments (see Kopár, 2012). Whether raised by Norse settlers or not, their riverine and maritime locations and distinctive recumbent character have also been regarded as indicating the mercantile activities and/or lordly status of their commissioners (Lang, 1984; Stocker, 2000; see also Richards, 1991: 164-65; Batey \& Graham-Campbell, 1998: 249-50; Hall, 2007: 102-13; Griffiths, 2010: 145-49; GrahamCampbell, 2013: 79-80; Carroll et al., 2014: fig. 3.4; 72-84).

This tradition of interpreting hogbacks as a coherent category retains some merit in the broadest terms. However, the existing approach remains mired in culture-historical thinking since it attributes a cultural label to these monuments and assumes they indicate a coherent hybrid 'Hiberno-Norse' or 'Anglo-Scandinavian' culture. As critiqued elsewhere for the Viking world, such ideas of colonial acculturation are restricting and unidirectional in their appreciation of social and cultural change (see Svanberg, 2003). This is particularly problematic for the medium of stone monuments of the tenth- eleventh centuries, in which many different pre-Christian and Christian influences may have been merged to create a range of novel material strategies of mortuary commemoration (see Jesch, 2015). The fact that no two stones are alike, and these stones involve many different sources of inspiration, makes the uncritical deployment of the term 'hogback' problematic at best.

Existing approaches can be profitably tempered by considering each monument as idiosyncratic personal commemorative monuments (e.g. Griffiths, 2010: 146). Still, the reasons why these stones share architectonic and zoomorphic similarities and connections in the broadest terms, and how these were apprehended in the context of the Viking diaspora, remain valid themes for further investigation.

To this end, rather than exploring the origins of Viking-age recumbent stone monuments, their distribution, or details of their form or ornamentation, I instead promote the importance of situating them in a broader archaeological context or 'material world' in the tenth and eleventh centuries. From this perspective, while the original source of hogbacks remains an important research question, their reception and varied deployment is the principal focus of enquiry. As part of the rising popularity of stone as a medium for commemorative endeavour, and the Viking-age emphasis on a range of new recumbent stone monument types in particular, hogbacks can be interpreted as being experienced in relation to a range of other bow-backed and beast-guarded architectures and artefacts operating through a range of scales and materials. In this context, recumbent stones can be considered as varied skeuomorphic architectural strategies for protecting and commemorating the dead as accessible and 'resident' within their tombs (see also Williams, 2015; 2016). This may have been particularly powerful as a commemorative strategy during a time of socio-political and ecclesiastical fragmentation but also a time of extended socioeconomic networks and exchange (Sindbæk, 2007; Ashby, 2015). While elsewhere I explore the mnemonic power of these architectural citations - creating the sense of solid space within or below hogbacks (Williams, 2015) - here I wish to explore the entangled web of citations to a range of materials with bowbacked forms, tegulated roofs, and guardian beasts found in broadly contemporary ecclesiastical and secular materials and architectures 
throughout the Irish and North Sea zones of interaction in the tenth and eleventh centuries $A D$. Rather than narrowing them down, this broadens further still the references and allusions hogbacks may have conjured up for contemporary audiences. Within the flowing ideas, people, and materials of the Viking Age, hogbacks can be reconsidered as less of an index of Hiberno-Norse settlement or influence per se. Instead hogbacks are considered powerful mnemonic agents through their meshwork of citations, perhaps serving to define and communicate senses of origin and identity within the Viking diaspora (see Jesch, 2015).

This perspective has many potential ramifications for Viking-age studies. First, the approach emphasizes the active role of materials in creating social worlds among Vikingage communities (e.g. Ashby, 2015). Second, it serves to critique studies of Viking-age architecture and material culture that investigate commemorative forms exclusively within particular forms, materials, or scales and instead explore them relationally. The argument re-situates recumbent-carved stone monuments as performative mnemonic devices by creating citational fields between things, but also between scales and media (Jones, 2007: 56-61; 68-80). The entanglement of hogbacks can be taken further by adopting Ingold's (2007) term 'meshwork' to understand the bricolage of material connections set up by individual recumbent stones and assemblages of monuments that accumulated at particular ecclesiastical locales (see also Williams, 2013; 2014; 2015; Williams et al., 2015).

The performative role of recumbent carved stones in mortuary technologies of remembrance is central to this approach (see Price, 2015; see also Williams, 2006; Price, 2010; Richards, 2011). Hogbacks may have not only marked single graves, burial plots, or cited graves located elsewhere, their scale and shape is certainly suggestive of a close association with the commemoration of the dead body and the tomb as a space in which the dead were regarded as residing and accessible, thus prompting an association between the hogback and an imagined, inhabiting presence of the dead (Williams, 2015). Moreover, hogbacks and other recumbent stones constituted and perpetuated memories of the dead through their public carving, installation, and use. Hence, rather than just marking and memorializing graves, hogbacks prompted and fostered embodied dispositions and actions by those encountering them (cf. Back Danielsson, 2015). In some respects, they operated in a way that is similar to the creation of furnished inhumation graves in the Insular world: assembling a web of allusions and biographies through the inclusion of a range of artefacts selected by the survivors. The parallel extends beyond the creation and display of the mortuary assemblage, since both furnished graves and carved stones were involved in the staged consignment to memory beneath a monument that was intended to remain an enduring feature of the landscape (see Williams, 2006: 170-78). The specific focus of this article is to explore hogbacks as technologies of remembrance and also involves exploring how they drew their commemorative significance from a meshwork of citations to other material cultures. To build this argument, I review the wide range of materials and media which were broadly contemporary with hogbacks and propose that they helped contemporary people apprehend their commemorative power.

\section{Citing Buildings}

Drawing on contemporary pictorial and archaeological evidence, Schmidt (1973) and Lang (1984) have already explored the shape of some hogbacks as reflecting the bowed roofs and walls of contemporary buildings in southern Scandinavia (Lang, 1984: 90-93). 
Meanwhile, their tegulation as thought to reflect these buildings' shingle roofs. However, Schmidt was mainly interested in using hogbacks to inform an understanding of Viking architecture, while Lang dismissed architectural allusions as 'purely decorative' (Lang, 1984: 93). Bow-walled and (postulated) bow-roofed buildings are now widely known from Scandinavia although they are rare in northern Britain (Jørgensen, 2003; Hadley, 2006: 1067; Christiansen, 2007; Schmidt, 2007; for a recent review, see Richards, 2011). Yet the active mnemonic significance of architectural citation for the mortuary significance of thes stones has not been investigated.

A key point remains that the varied architectural forms of hogbacks - not only their roofs but also their gable-ends as on the Lythe 32 (Lang, 2001: 165-66) and Cross Canonby monuments (Lang, 1984: 128; see Figure 2) - could have cited contemporary architecture, including elite tenth-century Trelleborg-style halls. However, this building form has earlier roots, as seen on the Hedeby coins of the early ninth century illustrating 'hogbacked' profiles framed by beasts (Graham-Campbell, 2013: 62-63; see Figure 5). If so, this may not have been merely a citation of the building itself, but of its architectural components and furnishings such as door lintels, benches, and beds. Moreover, what may have been referred to in the hogbacks is less the building itself than its many uses and significances as a focus of elite dwelling, repose, sleeping, feasting, ritual performances, and cult activities.

The identities of buildings may have been crucial too. Halls may have accrued famed lifehistories connected with their own construction, use, abandonment, and citation through new acts of building and burial (Thäte, 2007; Eriksen, 2013; 2016). As places where memories were produced through the biographies of their inhabitants, halls may have become famed structures with personalities of their own: 'living', 'dying', and 'dead' nonhuman agents (see Eriksen, 2016). Thus, selected buildings in the late Anglo-Saxon and Anglo-Scandinavian context may have been renowned, remembered, and actively commemorated long after their own demise. From this perspective, spectacular elite buildings, both tangible and imagined - like prestigious weapons and jewellery - may have acquired names and fame through their association with gods, heroes and kings, famed vehicles and beasts, as exemplified by the illustrious hall of King Hrothgar in the poem Beowulf: Heorot (Bradley, 1982).

In the archaeological record, the mnemonic power of famed halls is strikingly revealed in the Scandinavian Vendel and Viking periods in the curation of individual buildings and their rebuilding over the same (or similar) footprints for centuries, as evidenced at the highstatus complex at Tissø on Funen in Denmark (Jørgensen, 2003). A further strategy for commemorating halls is recognized elsewhere: the building of new halls in positions adjacent to earlier foundations. In this instance, the locations of earlier halls may have been venerated and respected, perhaps as elements of mythologized landscapes, and in order to honour their presence, perhaps linking them to legends about their former occupants. The sequence of halls known from Lejre in Denmark may be interpreted in such mnemonic terms: honouring ancient halls by building new ones in close proximity (Christiansen, 2007; Lund \& Arwill-Nordbladh, 2016). Moreover, the close proximity of halls and ancient burial mounds were elements of wider topographies of memory at these Late Iron Age central places. In this sense, hogbacks can be seen as a further way by which the past was mobilized by citing elite habitations through the medium of stone. Otherwordly dwellings 
might be evoked too: Odin's Valhalla could be envisioned, as suggested for the commemorative context of the hog-backed hall on the Gotlandic picture-stone known as Tjängvide I (Schmidt, 1973: 63; Graham-Campbell, 2013: 161; see also Eriksen, 2013).

Alternatively, the shrines of saints, or the churches of Rome or Jerusalem, may have been evoked through the allusions to canopies displayed by the recumbent stones (Lang, 1984; Williams, 2015, see below).

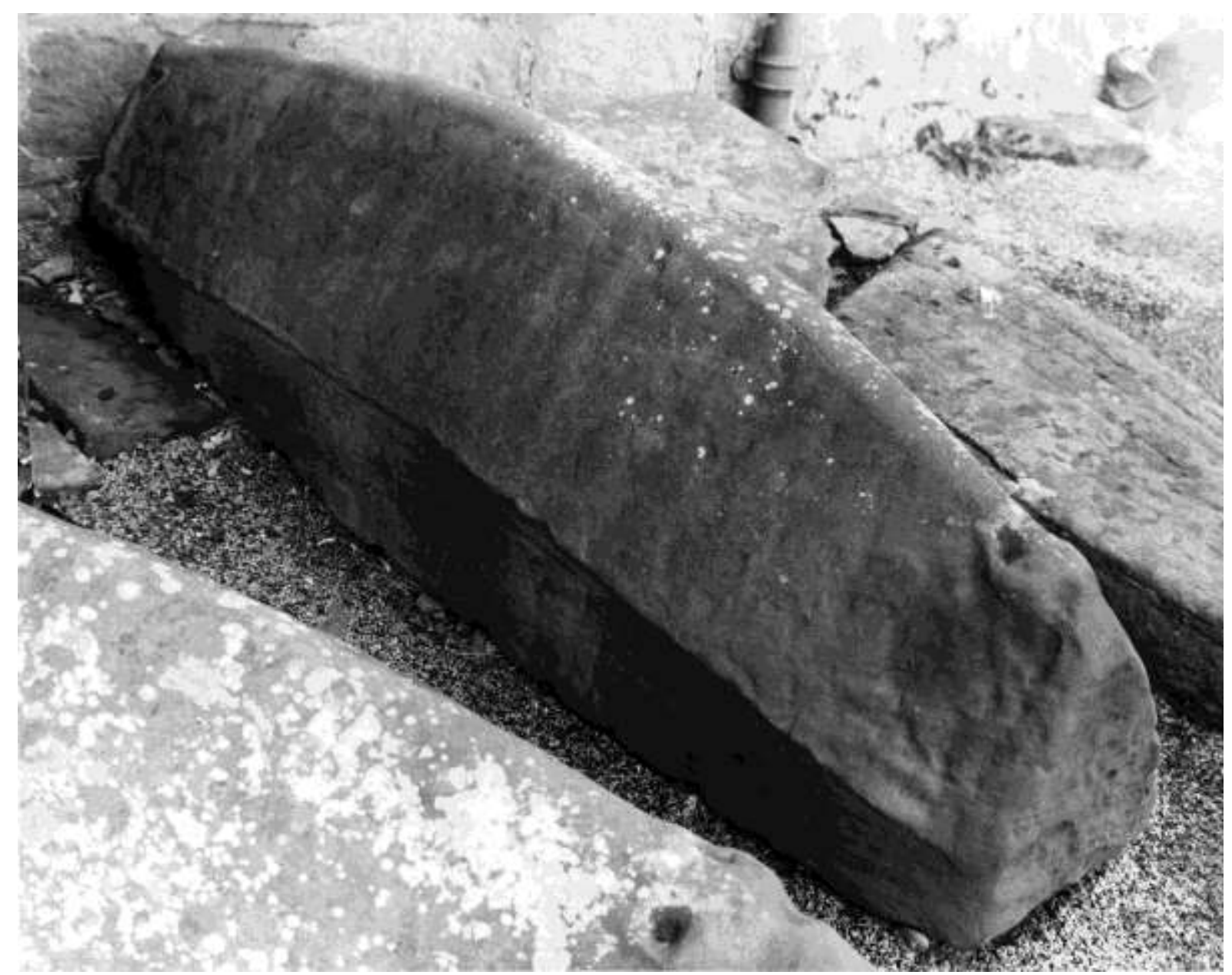

Figure 2. Cross Canonby 5C/D (Cumbria): hogback, type f (after Bailey \& Cramp, 1988, pl.

233). By permission of Corpus of Anglo-Saxon Stone Sculpture, University of Durham (photograph by $T$.

Middlemass).

The building citations of hogbacks are enhanced, rather than diluted, when we recognize that their citations need not be exclusive to halls, but to other key buildings on Viking-age magnate farms and central places. Since earlier writers have commented on the skeuomorphic dimensions of hogbacks, monumental and long-lasting pagan temple structures have now been recognized in the archaeological record from southern Scandinavia: an example, discussed by Larsson (2010), is the stave-built structure built around AD 200 and dismantled in the middle of the tenth century at Uppåkra in Scania, Sweden. More plausibly, given the British context, Christian chapels and churches, as loci for elite burial and commemoration and as places of worship, may have readily been cited by recumbent stones installed within or close to them. While no bow-sided church buildings have been conclusively found in the British Isles (Richards, 2011), one might anticipate shared building techniques for both halls and churches in instances when timber was used 
for construction (or indeed stone, given the many skeuomorphic dimensions of late AngloSaxon stone architecture) in the same locales, or at least a recognition that the form alluded to dwellings as well as to places of worship (see Stocker, 2000).

Boathouses are another kind of structure which certain carved stone monuments may have cited. They are a key component of maritime communities for the storage and repair of seagoing and riverine craft (see Stylegar \& Grimm, 2005). As prominent elements of highstatus maritime settlements, they were often built with a comparable bow-sided shape, as at Spangereid, Vest-Agder, Norway (Stylegar \& Grimm, 2005: 261-63). It is plausible that, in some instances at least, they were designed to have, or accrued, associations with the dead and the past, especially when boathouses were built close to boat-graves and when boat-graves were perhaps constructed to resemble boathouses (Herschend, 1997).

Furthermore, the vessels they contained may have been regarded as famed and animated artefacts with complex biographies of use and reuse of their own, prompting their reuse, whole or in fragments, as conveyors, structures, and containers during mortuary ritual.

Buildings connected to land transportation might have been important too. In light of the striking evidence from the later phases of the Danish magnate farm of Tissø (Jørgensen, 2003), stables as well as buildings used to store carriages, carts and sledges can be regarded as prominent components of elite residential compounds. Meanwhile, smithies, which were key elements of Viking-age aristocratic farms (Jørgensen, 2003), and thus structures in which prestigious and famed artefacts were made for display, use, and exchange, may also have been alluded to in the architectural form and ornament of hogbacks. This example is especially pertinent given the evidence from Gotlandic picture-stones which show that smithies may have had comparable curved roofs (Lang, 1976: 91).

Drawing these strands of evidence together, I argue that recumbent stones accrued and intensified their commemorative impact by simultaneously citing a network of mythical, legendary, and remembered structures, perhaps including halls, temples, churches, boathouses, smithies, and stables. Indeed, the shape and tegulation of hogbacks might imply relatively small-scale canopies or even tents as well as these more lofty elite-built environments. This discussion provides context for the stylized scenes on the side panels of certain illustrative-type hogbacks. Here they may depict buildings not simply as elite dwellings, but as ceremonial spaces with thresholds to allow the dead to come and go (see also Williams, 2015). There is a bird of prey and a lady on Sockburn 15A (reflecting a common adventus motif in Viking-age art found in many settings, including on the Gosforth Cross: Bailey, 1980: 126; Bailey \& Cramp, 1988), riders on Sockburn 14A and representations of armies on both land and on a ship on Lowther $4 \mathrm{~A}$ (Cumbria).

In all these instances, the context of a recumbent stone may not have been arbitrary but significant in relation to terrestrial and maritime departure from, and arrival at, buildings (whether Valhalla or other prestigious destinations, both in this world or the next: see Kopár, 2012: 131-32). Likewise, there is a depiction of the magical smith Volundr in his flying machine on the side-panel Bedale 6A (North Yorkshire). In such cases, are we looking at an implied connection with the smithy used as a prison from which the hamstrung smith subsequently escapes having exacted his revenge upon the king's sons and daughter, as recounted in the thirteenth-century Völundarkviða edda (Larrington 2006)? This chimes 
with the Volundr scene on Bedale $6 \mathrm{~A}$ as a horizontal escape, a representation also found of a bird-man grasping an aristocratic woman and exiting a smithy on the Ardre VIII picturestone from Gotland (Lang, 1976: 91; see also Staecker, 2006: 363-64). As mentioned above, the smithy on this stone is depicted as a bow-roofed structure on the Gotlandic scene. In this sense, I suggest that the Bedale stone conceptualized through the metaphor of metalworking within a canopied structure, a place of death but also a place of regeneration and reproduction? This might relate to concepts of the soul as protected within the stone, guarded by its decoration but ready to escape to Heaven. Was Bedale, as one particular permutation of hogbacks architectonic significance, being rendered a stone smithy and/or a treasury temporarily containing the smith, the smith's tools and products of the smith's labours, all awaiting Salvation (Figure 3)?

It is perhaps telling that the one possible depiction of an indoor scene on a 'hogback' is a man seated in a chair with large bossed terminals on the gable-end of the same Bedale monument. Lang speculated that this might be a representation of King Nidud seated within his hall with a horn or cup on his lap, perhaps one of the vessels made by the smith. If so, he is depicted as receiving Volundr's cursed gifts: vessels made from his sons' skulls (Lang, 1976: 92-93; Bedale 6B: Lang, 2001: 62). The scene is far from clear, even with the high-quality photographs of the Corpus of Anglo-Saxon Stone Sculpture. Whether we adopt this specific reading or not, the image of a seated lord finds resonance on tenthcentury crosses from elsewhere in Yorkshire at Nunburnholme and Middleton (Lang, 1991: 182-84 and 189-93). Was Bedale's hogback the smithy of Volundr, the hall of Nidud, or somehow it alluded to both? While only a minority of recumbent stones have figural scenes, these images reveal varied and sophisticated citations to stories upon hogbacks. The 'mythological scenes' on some hogbacks further informed their varied and distinctive commemorative significance as dwellings for the dead.

Hadley has noted that the multivocality of tenth-century sculpture may have simultaneously appealed to diverse audiences who could have read them differently (Hadley, 2008), and Bailey (1980) has long argued that sculpture with 'pagan' imagery need not be regarded as 'pre-Christian' or non-Christian (see also Kopár, 2012). Secular and 'pagan' allusions can be closely connected to a mesh of relations between clerics and aristocrats in tenth-eleventh-century northern Britain. These need not necessarily represent either 'pagan' stories or exclusively Christian didactic uses of the pre-Christian past, but perhaps they invoked ancestral connections and specific honoured personalities through the medium of widely circulated and performed legends (for a parallel from Gotland, see Staecker, 2006: 366). Combined with this wealth of possible architectural allusions to real-world and mythological buildings, and indeed the multiple structures that existed within any single elite farmstead, the variability in monument designs looks less a failing and more a strength in terms of these monuments' commemorative efficacy. It is likely that hogbacks were never sculpted to cite single buildings at all, but that they evoked a range of architectural allusions with both socio-political and cosmological ramifications. Their citations created an aura of protected, sturdy, and famed dwellings acting as doorways into many potential narratives and significances from whence journeys began and ended. In this regard, the scale of hogbacks was crucial. Allusions to buildings in miniature may have been construed as distilling and concentrating these qualities and 
standing for the network of socio-political and religious relationships linking the lord to his kin, retainers, heirs, ancestors, heroes, and the supernatural.
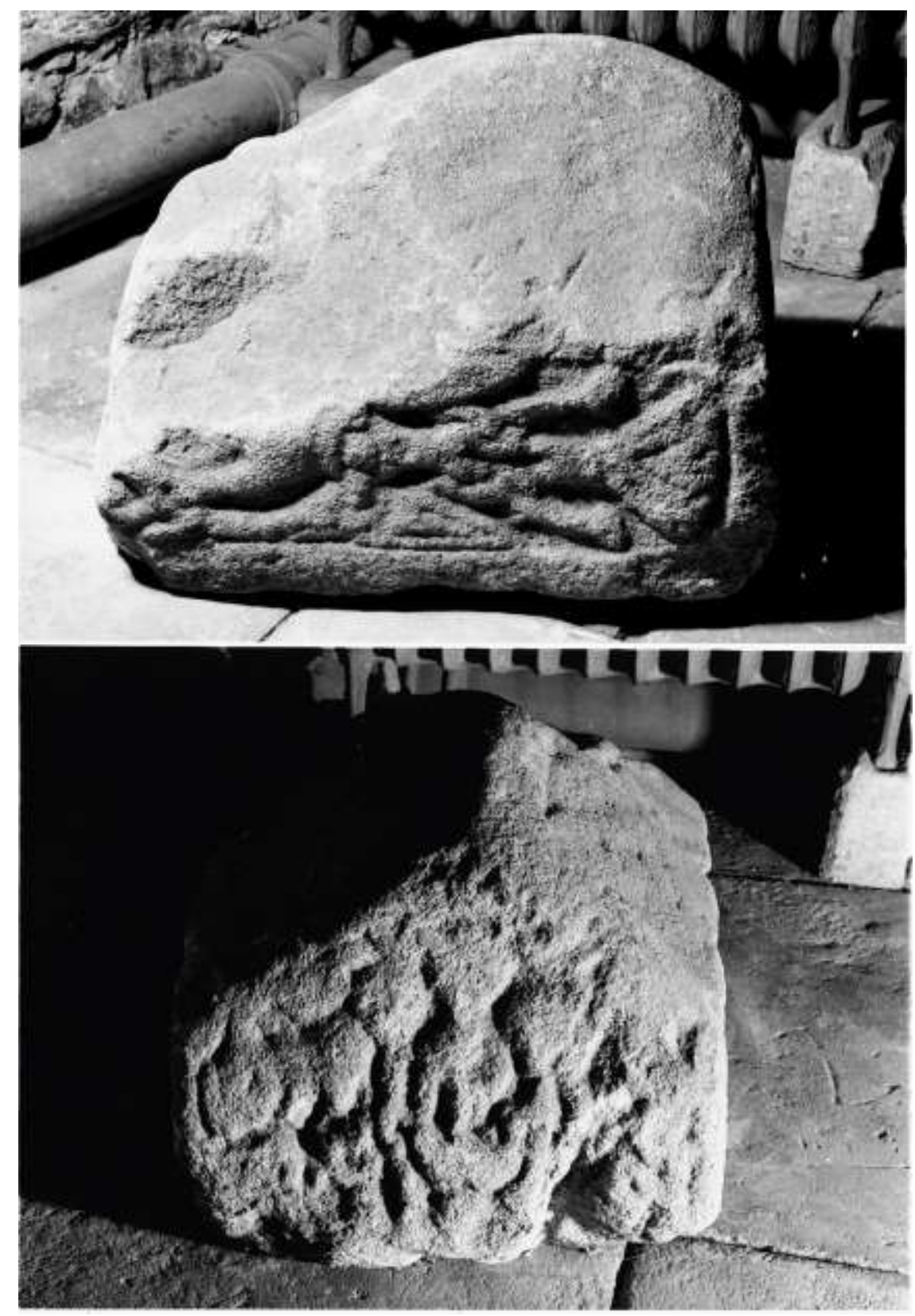

Figure 3. Bedale 6A (above) showing the motif of Volundr (Weland) within his bird-like flying machine, and 6B (below) seemingly showing a central seated figure framed by standing figures, interpreted by Lang to possibly represent Volundr's imprisoner, King Nidud, enthroned within his hall and receiving the smith's cursed gifts, hogback, type k (after Lang, 2001, pls. 23 and 24). By permission of Corpus of Anglo-Saxon Stone Sculpture (photograph by A. Wiper).

\section{Citing Tombs and Shrines}

Mortuary and sacred architectures should also be considered as part of this citational meshwork. In view of the later literary traditions surrounding the dead as mound-dwellers (e.g. Gardeła, 2013), recumbent stones may have materialized the sense of chthonic homes (Williams, 2015). As Lang noted, hogbacks are not simply miniatures of contemporary bowsided buildings with shingle roofs, they were arguably skeuomorphs of shrinetombs 
which draw on a long tradition of house-like tombs stretching back to Late Antiquity (Lang, 1984: 95). The potential significance of a canopied structure to imply the Tabernacle containing the Ark of the Covenant, or indeed the Temple of the Holy Sepulchre - the latter depicted with features comparable to hogbacks in the Book of Kells - should not be dismissed as esoteric and obscure (see also Lang, 1984: 95). Further, as Brown (1981) has shown, the resting places of saints were the most powerful medium of mortuary residence in Late Antiquity. Throughout the Middle Ages, the holy dead were deemed present and efficacious through her/his relics located within a built space. Moreover, reliquaries were not only portable items in themselves, but could constitute elements of other monuments, as widely noted for the tops of Irish high-crosses (Schmidt, 1973: 73; Bailey, 1980: 92-94; Lang, 1984: 95). When discussing hogbacks, references are regularly made by scholars to Bede's written accounts of St Chad's wooden tumba (Colgrave \& Mynors, 1979; see also Bailey, 1980: 95; Lang, 1984: 95) and we now have a clearer sense of its possible stone successor in the Lichfield Angel limestone panel from a shrine chest (Rodwell et al., 2008). Specifically, the solid Anglian tomb-shrines like Dewsbury (West Yorkshire; Coatsworth, 2008: 147-48) and the Hedda Stone from Peterborough Cathedral (Bailey, 1980: 95) provide closer Insular lithic exemplars.

That the memorials of the dead were akin to the shrines of saints was a concept widely adaptable for both the later Anglo-Saxon secular elites and their religious counterparts who were the patrons of the stone sculpture in the parts of northern Britain where recumbent stones had emerged. In a sense, being buried within or beneath a house-shaped tomb was a form of prospective memory; projecting an aspired afterlife onto the landscape and affording a focus for prayer and devotion (see Williams, 2006: 20-35). Recumbent monuments thus ensured a saint-like survival of corporeal integrity for the elite dead until Resurrection and as a presence in the church or churchyard. In doing so, monuments created a parity between, and integration with, secular and sacred architectures as built spaces protected by the static gazes and enwrapping bodies of attendant ursine or dragonesque beasts. Indeed, this apotropaic theme in figural and animal art is deeply embedded in Insular commemorative practice as argued for the seventh-century coffin of St Cuthbert, located in Durham since AD 995 (see e.g. Ní Ghrádaigh \& Mullins, 2013). The 'influence' of shrines on their form may have therefore been a conscious and overt manipulation of elite Insular iconography to portray the dead as powerful but also pure in soul. From this perspective, the recumbent stones cited similar-sized shrine-tombs as much as they operated as miniatures of buildings. Hence, as emphasized by the Heysham monument in Lancashire (Bailey, 2010: 201-4), where bear-like beasts are carved to serve as a frame for the roof-like canopy of the monument, the interpretation is that they are supporting and sustaining a portable framework as much as a building. Thus, stones simultaneously imply permanence and movement fossilized in stone.

This interpretation also applies if we consider the possibility that other hogbacks were influenced by elite mortuary practice in Viking-age Scandinavia. As Lang (1984: 91) aptly noted, relationships with the Scandinavian homelands cannot be completely disregarded, since both chamber-burial and boat-burial could employ house-like structures; further, boatgraves could have had tents within them, as argued for the boat-graves at Valsgärde, Uppland, Sweden, and as revealed in the Oseberg and Gokstad mounds (as discussed, among others, by Price, 2010). In these ways, they operated as tangible dwellings for the 
dead for some unknown duration before being covered over, during which time rituals and ceremonies were performed. Subsequently they served as imagined spaces, implying afterlife embarkation, after a stones etting, cairn, or earthen mound was raised (see Williams, 2014). Indeed, many boat-graves in eastern Scandinavia may have never been covered over and remained visible as 'boathouses' for the dead (Williams, 2014). This may add weight to the possibility, referred to in later literary accounts of mound-dwellers, that there may have been varied manifestations of Viking-age mortuary practice: not simply chamber-graves (see Gardeła, 2013), but a range of structures and spaces affording tangible and implied residences and corporealities for both the inhumed and cremated dead (see Williams, 2013).

Equally significant are the much discussed long-term archaeological, art-historical, pictorial, and textual data for the influence of the longue durée of Christian commemorative tradition of constructing building-like (and perhaps originally beast framed) biers and coffins; this includes the purpose-built Alemannic zoomorphic coffins from Oberflacht in Baden-Württemberg (for discussions, see Tweddle et al., 1995: 279; Hall, 2015), as well as evidence from Anglo-Saxon and Anglo-Scandinavian contexts for the use of boats and boat parts (Brookes, 2007). Furthermore, bed burial is known from the seventh century across England (Sherlock, 2012) and domestic chests deployed as biers and/or grave structures is a widespread minority practice, perhaps linked to the social status of the deceased (Craig-Atkins, 2012). Indeed, the female-gendered bed burial in grave 42 in the seventh-century cemetery of Street House, Loftus (North Yorks.) may have once had a gable-roofed canopy above it, perhaps subsequently covered with a mound (Sherlock, 2012: 107-11). This provides a striking Insular funerary precedent for the Viking-age hogbacks. If beds were embellished with beast-protected metalwork, framing the sleeper in a comparable manner to the depiction of the Christ-child adored by beasts in his manger on the Sandbach north cross (Hawkes, 2002: 46-49; Bailey, 2010: pl. 264), then Insular parallels may have been closer than is often perceived. However, there are examples of well preserved coffins and chamber-graves from Viking-age Denmark that provide parallels too (Brønsted, 1936: 107 and 134-35).

A further hint that the role of hogbacks mirrored wider wooden traditions of constructing mortuary structures is found in the burial plot at the eastern end of the late Anglo-Saxon churchyard at Raunds (Northants.). Here, two posts framed an east-west slot running along, and defining, the northern edge of a burial plot where five burials were laid out, involving the intercutting of four successive graves (Boddington, 1996: 50). If this constitutes a timber equivalent to a 'hogback' placed between upright markers or standing crosses (an arrangement often suggested, see Bailey, 1980: 99-100; Lang, 1984), then it is possible to suggest that stones sometimes functioned as burial plot markers rather than grave covers in Anglo-Scandinavian churchyards. The significance of recumbent monuments therefore need not relate to the identity of individuals but to families or households.

It is also important to recall the significance of tents or pavilions, especially given that much of the interlace designs on stones could readily imply skeuomorphs of leather or textile as well as wooden coverings (see also Williams, 2015). These are well attested as elements of middle Anglo-Saxon elite mortuary practices, such as the tent used to surround the grave 
during the exhumation of the Abbess Etheldreda (Colgrave \& Mynors, 1979). Such devices, used for the conveyance and protection of the body to the grave, constitute evidence that is especially pertinent if the bears that constitute end-beasts on hogbacks at Brompton and elsewhere (Figure 1) are deemed to be beastly pall bearers, raising up the canopy with their paws and jowls.

In stone, the beast-framed grave covers from York Minster are flat versions of the same broad concept as hogbacks with prominent ursine or serpentine end-beasts; a beastbounded and secured surface through which the living might not readily venture through, which implies a space existing beneath/within the stone (Lang, 1991: pls. 159 and 165). Therefore, if the aim of the stones was to convey a sense of a beast-protected 'home' or 'bed' for the soul of the dead, whether marking their grave or located away from the body, then this has a wider range of parallels in the juxtaposition of humans battling beasts and monsters in Viking-age sculpture, such as the tenth-century grave markers from York Minster 35, 37, and 38 (Lang, 1984: 96-97; see also Thompson, 2003; 2004). The materiality of the tomb thus anchored and bound the souls of the dead as devotional and commemorative loci (Thompson, 2003; 2004; see also Williams, 2015). Yet here again we must balance Insular parallels for architectural allusions in stone with Scandinavian examples such as the box-tomb from Ardre, Gotland (e.g. Graham-Campbell, 2013: 149).

\section{Citing Small Things}

So far we have trodden relatively familiar ground but extended and restructured previous discussions of the influences on hogbacks as material citations to a spectrum of contemporary buildings, tombs, structures, and furnishings. What has yet to be fully explored is how hogbacks may have operated not only as miniatures and citations to samesized media, but may also have cited, through their form and ornamentation, a wide range of portable artefacts and diminutive material cultures circulating throughout the Viking world. I shall not attempt a comprehensive survey here, but highlight potential relationships with portable artefacts such as liturgical and ritual paraphernalia, dress accessories, weapons and armour, grooming implements, caskets, and chests. This discussion extends earlier arguments calling for more careful consideration of the power of small things in the commemoration of the dead, both as theatrical props (see Price, 2010) and as intimate and sensitive commemorative catalysts in the social and mnemonic transformation of the dead (Williams, 2013).

To date, portable reliquary shrines of Irish type have been cited as possible inspirations for hogbacks. Lang recognized that these reliquary shrines pre-dated the Viking Age but circulated within it, as evidenced from the range of Scandinavian furnished graves containing their fragments; he also cites the caskets from Bamberg and Cammin as potential parallels (Lang, 1984: 95; see also Schmidt, 1973: 67; Graham-Campbell, 2013: 111-14). This evidence alone suggests that hogbacks were not simply skeuomorphs of buildings or influenced by contemporary same-sized shrine-tombs, they were also gigantisms of smaller artefacts with architectural, beastguarded forms. As Lang put it, the hogback was a 'skeuomorph of a skeuomorph: a grave cover designed as a casket which is in turn based on a building' (Lang, 1984: 95). However, this view unnecessarily contrives a simplistic succession of influence. It omits awareness of the other architectural grave structures that create a context for recumbent stones outlined above. These include a 
range of links to Christian artefacts from the tops of Irish high-crosses (Bailey, 1980: 92-94) and the resemblance of hogbacks to beast-adorned and church/hall-shaped Insular caskets and reliquaries, which may have been circulating across the British Isles in the Viking Age (Bailey, 1980: 94-95; Youngs, 1989: 136-40; Edwards \& Gray Hulse, 1992; Henderson \& Henderson, 2004: 115-16; Webster, 2011: 480-82). Moreover, the significance and association of shrines with recumbent stones should not be dismissed simply because of issues of contrasting scale and material. For example, the Bologna reliquary possessed inward-facing wide eyed beasts on its ridge finials and the backplates, suggesting the possibility of seeing parallels with hogbacks (see also Bailey, 1980: 89). In particular, the fastening of the end-beasts' mouths with their own paws on Brompton 24 parallels the action of fastening shut the lids of house-shaped shrines like the Bologna and Monymusk reliquaries (Lang, 2001: 77-78).

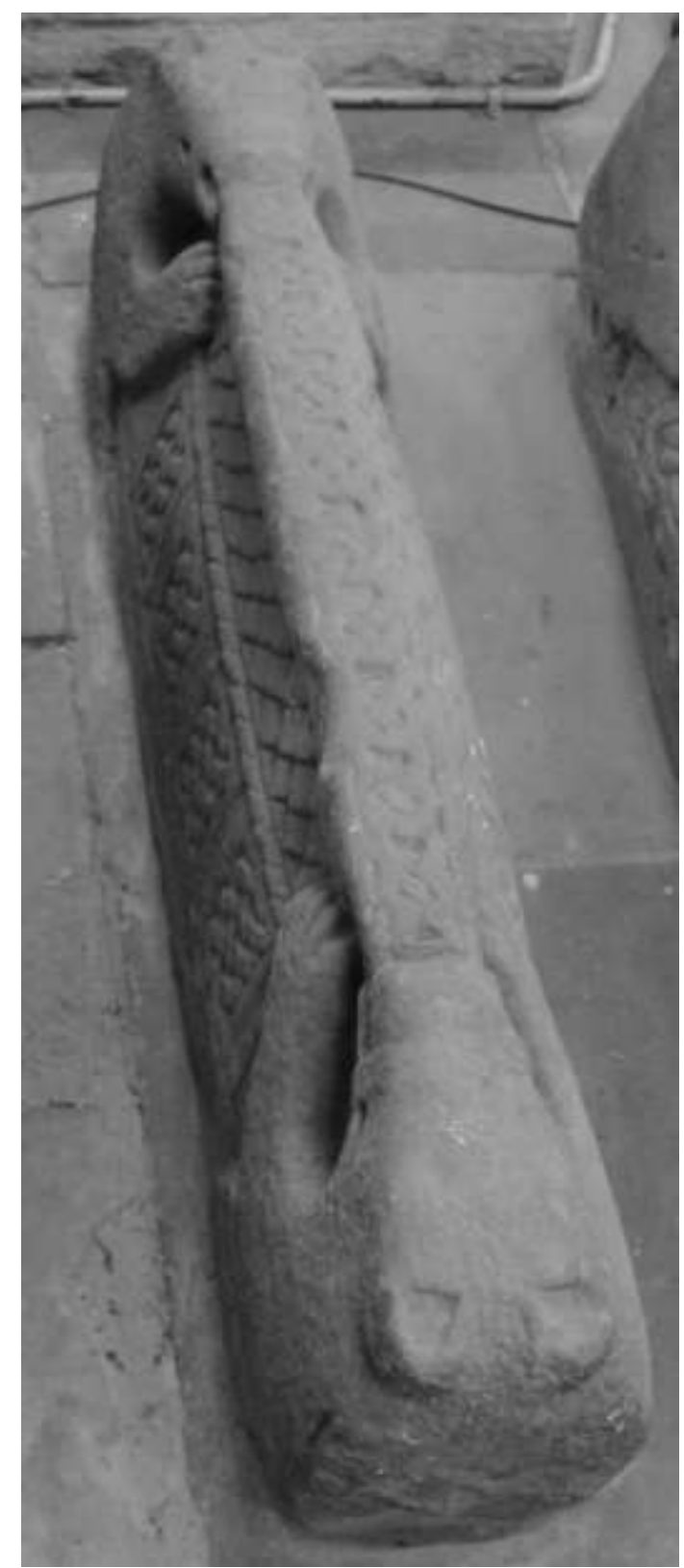

Figure 4. Brompton 17. Photograph by Howard Williams. 
Furthermore, the chain of copper-alloy wire linking together the hinges of the Bologna reliquary also evokes the emphasis on tight interlace and chains on the ridges of many stones including Brompton 170s ring-twist pattern (Lang, 2001: 74; see Figure 4). In addition, it should be noted that shrines were circulating widely, fragmented and reused as dress accessories and on weights within the Viking world, as the fragments of a 'tombshaped shrine' retrieved from the Islandbridge cemetery, Dublin (Harrison \& Ó Floinn, 2004: 202-3) illustrates.

Parallels with Insular ecclesiastical artefacts extend beyond reliquaries. There may have been further house-/church-shaped artefacts circulating in the material environs of hogbacks, including the eleventh century copper-alloy house-shaped cover discovered in Pershore, Worcestershire, with a tegulated roof adorned with beast heads (Webster, 2011: 202). We might also note the curved shape and beasts adorning the terminals of Insular croziers, like the eighth-century example from Helgö, Sweden (e.g. Youngs, 1989: 152). While not displaying an architectural form, such beasts may have provided further parallels to the range of ecclesiastical objects framed by beasts. The same argument could be extended to bell shrines (e.g. Batey \& Graham-Campbell, 1998: 104).

Considering the Bamburg and Cammin caskets, as well as the León antler box (GrahamCampbell, 2013: 114-15), we should also take into account the world of largely lost chests and other containers that may have inspired, and been cited by, recumbent stone monuments. Indeed, the famous tool chest from Mästermyr, Gotland, exemplifies the kind of containers that may have been in circulation and used to contain worldly and sacred treasures, and (as discussed above) sometimes been reused as coffins (Arwidsson \& Berg, 1999: 7-8). Smaller items still may have been key to the significance of hogbacks. Both Schmidt (1973: 66) and Bailey (1980: 86-91) cite the mid-tenth-century Trelleborgstyle bronze miniature house found in the cremation burial at Klinta, Öland; it is framed by four embracing beasts fixed on the top of an exceptional iron staff.

However, this artefact and its funerary context have only more recently been given more detailed attention, suggesting that this may have been a 'staff of sorcery' (used in ritual ceremonies and spun to imitate distaffs and/or to mimic the turning of keys; Gardeła, 2008: 57-58) cremated with its seeress (Price, 2002: 183-85; Gardeła, 2008; 2009; 2012, but see also Gustin, 2010). Gardeła (2009: 205-7; 2012: 307-8) even speculates that the animal representations on the Klinta staff could represent the guardian spirits of the seer, perhaps those whose bones were employed in the manufacture of the item (see Back Danielsson, 2007). While an exceptional find, it is possible that such shamanistic artefacts acquired new and varied significances during the Viking diaspora in which beast-guarded buildings were mediators with the supernatural (see also Eriksen, 2013). A further point of interest is that, when placed in the Klinta grave, the building projected upwards through the lid of clay daub sealing the rich cremation grave, thus making the staff a material intermediary between the burial pit and the world above. The beasts represented are possibly bears. Certainly the funerary context underpins an ursine connection: bear bones were found, perhaps indicating the presence of animal pelts cremated with the female in the pit and/or the remains of the male individual spread over it (Price, 2002: 145 and 147). However, rather than focusing exclusively on pagan or Christian artefacts with overt ceremonial roles and associations, it is perhaps the network of artefacts used in daily life among elites and their 
retainers in the tenth century that must be emphasized. These include dress accessories, grooming implements, and containers, and we can discern many more allusions to such artefacts among hogbacks. Hence, I would suggest that architectural forms akin to recumbent stone monuments were far from being restricted to items with Williams possible magical connections. Instead, I would propose that the combination of outwardand inward-looking guardian beasts framing 'hog-backed' architectural structures is frequent in small-scale metalwork and other Viking-age material cultures.

One unique object, a strike-a-light with Borre-style gripping beasts, was found in a settlement context at Tæbring, Denmark; its form and decoration present a marked 'similarity with a group of so-called hogback gravestones in Northern England' (Mikkelsen et al., 2008: 84-85). Another class of objects which resembles hogbacks in miniature is female-gendered dress accessories with Borre-style 'gripping beasts' (e.g. Hall, 2007: 175; Graham-Campbell, 2013: 67-69). These include the oval brooches widely recognized in northern Britain and Ireland (e.g. Batey \& Graham-Campbell, 1998: 177; Kershaw, 2009; Griffiths, 2010: 92, 94). Their bowshaped profile, plus the zoomorphic decoration on some examples like those from Cárn a' Bharraich, Oronsay, makes them broadly comparable with hogbacks. There are even ursine connections, as, for example, in the exceptional case of a pair of gilded copper-alloy oval brooches with silver inlay (one heavily fragmented, the other well preserved) found at Church Street, Finglas, north-west of Dublin, in a furnished grave of a woman aged between 25 and 35 years (Sikora, 2010). Each brooch has traces of cast gripping-beast motifs as well as protruding decoration of two types. If the brooches were indeed identical, each would have originally had four bear-like heads and five bearlike beasts (as if seated) on the back of the artefacts, one at each edge and one central (Sikora, 2010: 410). All of these fittings are made of brass and all the bears would have once possessed glass eyes (Sikora, 2010: 414; see also Harrison \& Ó Floinn, 2014: 134-36). Nor is this theme restricted to 'Norse' artefact types; Insular artefact types also exhibit curved profiles and animal-ends, such as the penannular brooch of eighth century date from St Ninian's Isle, Shetland (Youngs, 1989: 112 and 192).

Like the Finglas grave, many other female-gendered-furnished grave assemblages, like that from Cnip, Lewis, Scotland (Batey \& Graham-Campbell, 1998: 75), contained another category of artefacts which may have visually resonated with hogbacks: antler combs. They are most frequently discussed in relation to craft production and trade, but increasingly regarded in a broader context of Viking-age lifeways and identity negotiation, including their deployment in mortuary practice (Ashby, 2014). As Gansum (2003) has already observed, combs are likely to have been part of a broader symbolic repertoire embodying identity that connected grooming implements, helmets, halls, and metalwork in the later first-millennium AD in Scandinavia. In the light of this article's discussion, it is worth noting that many of the single-sided combs of the Viking Age have zoomorphic terminals and a 'hogback' form which finds a close parallel in the arrangement of recumbent stones (e.g. Batey \& Graham-Campbell, 1998: 106; Ashby, 2014). Indeed, perhaps it was the combs together with their comb cases that provided the material referents for hogbacks even more than the combs in isolation: the comb concealed within its case (Ashby, 2014: 108-9).

Martial male-gendered items circulating throughout the Insular world during the Viking Age, such as sword pommels (e.g. Pierce, 2002: 30-31; 96-97) and chapes (e.g. the St 
Ninian's Isle hoard chapes: Youngs, 1989: 154), could be regarded as sometimes exhibiting the hogback attribute of having curved backs. Examples include the Petersen Type $D$ and $E$ swords from Kilmainham (Harrison \& Ó Floinn, 2014: 78-81). While few have guarding beasts, they might be seen as similar in shape to large hogbacks like those from Govan. Another item with a bowed profile and architectural allusions are the harness bow mounts found in Scandinavian contexts such as that recovered at Mammen (Denmark); some have been argued to represent in miniature the gable-ends of halls (Dobat, 2006: 185; GrahamCampbell, 2013: 84-85). At least one example is known from North Yorkshire, adding plausibility to the idea that they were part of the material world of hogbacks $n$ (GrahamCampbell, 1998: 101-2).

Further instances of architectonic artefacts could be identified, but these examples suffice to illustrate that hogbacks may have functioned not only as skeuomorphs of buildings, structures, and caskets, but as a constellation of other material cultures and materials circulating in tenth-century Britain and Ireland. Furthermore this entanglement of material things, rather than individual artefact types in isolation, constructed and commemorated a form of personhood in life and death created by the circulation of material cultures (see Klevnäs, 2016). Equally, it is clear that these citations were not gender-specific: beastguarded architectures straddled the male and female gender spheres. This supports the suggestion that a possible role for the hogbacks was that of memorials to families or households as much as individuals in death (see also Hadley, 2008). Returning to Klinta on Öland, we have a high-status tenth-century-cremated grave assemblage where a range of artefacts, in different forms, materials, and scales, shared architectonic attributes. These included the 'seer's' staff (discussed above), oval brooches, a saddle-bow, barrels, a casket, and even the shape of four hammers on a Thor's Hammer ring, as well as the bones (thus presumably the skins) of a bear or bears (Price, 2002: 143-49; Svanberg, 2003: 132-32; 25253). It is tempting to regard the hogbacks as setting up, in different ways, allusions to such multifaceted mortuary assemblages as much as miniaturising individual categories of monuments and architecture (Figure 5). 


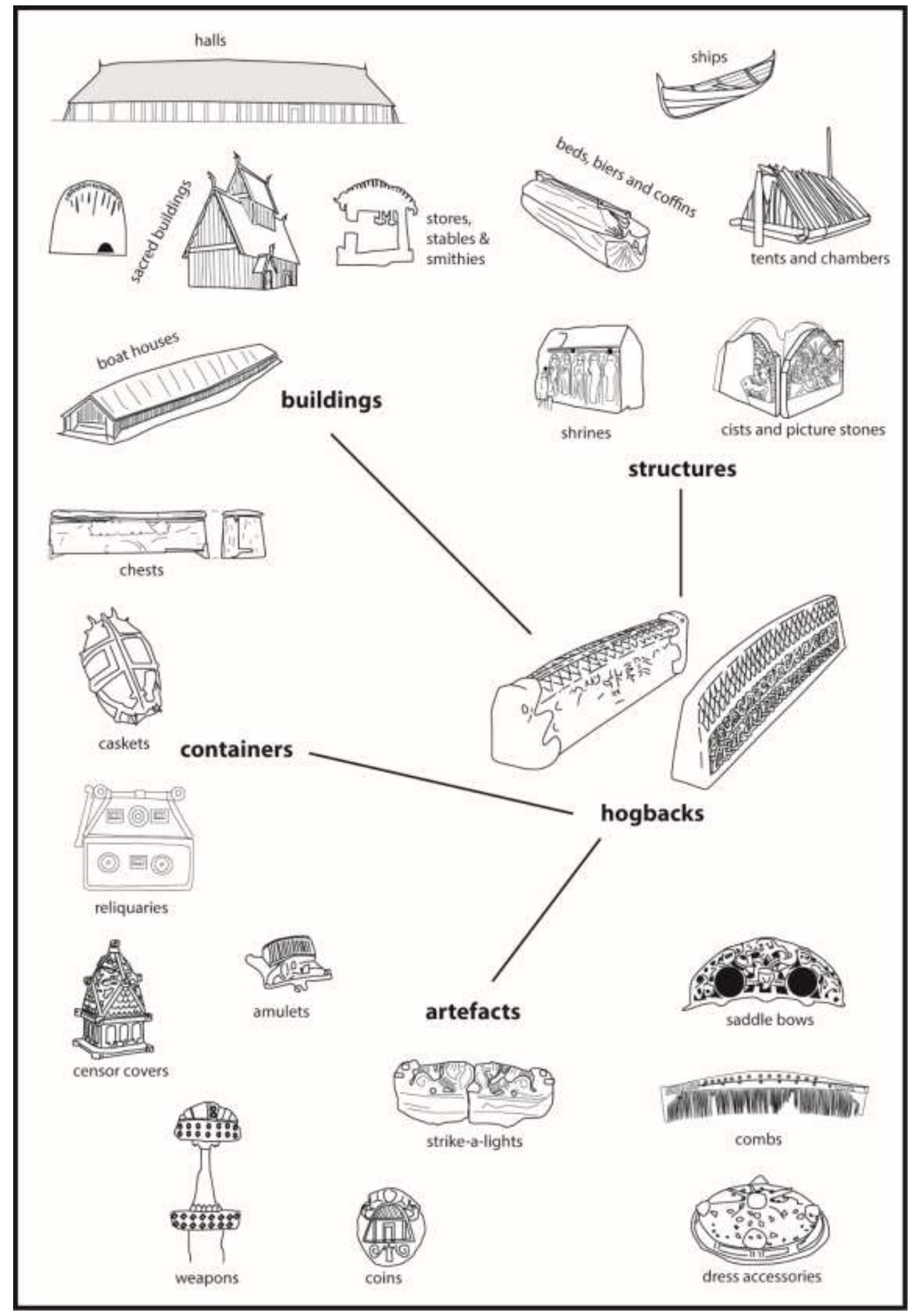

Figure 5. Schematic of the meshwork within which hogbacks most likely were apprehended in northern Britain during the Viking Age, incorporating Insular and Scandinavian artefacts from throughout the Viking world and discussed in the text as illustrative examples. 


\section{Conclusion}

While scholars of early medieval stone sculpture have long explored the rich interplay between stone sculpture and a range of other media (especially metalwork; see Hawkes, 2003; summarized in Williams et al., 2015), to date, research has not considered meshworks of citation as an active and discursive Viking-age commemorative strategy straddling form, ornament, and also the interplay between different materials. 'House-shaped' recumbentcarved stone monuments known as 'hogbacks' appear to carefully deploy citations to a range of other architectural media, involving their form, ornamentation, materiality, and perhaps also the location of recumbent stone monuments over graves or marking burial plots. Mortuary carved stones might have gained commemorative efficacy, not through their exclusive association with particular materials or scales of object, but to a multimedia and multi-scalar material world involving halls, shrines, animals, and portable artefacts. This perspective reflects a broader, complex interplay of scales, forms, and citations, which seems to have permeated both Insular and Scandinavian societies before and during the Viking Age and focused on allusions to canopied and beast-guarded structures (cf. Back Danielsson, 2007).

In fact, the one item of early medieval material culture that visualizes this material world most effectively is a textile: the Bayeux Tapestry. Within this 70-m-long embroidery, we encounter buildings, shrines, ships, biers, and other canopies that vary in colour, shape, and function, but incorporate similar beast-framed bowshaped forms. While I do not propose this as a precise model for the relationships of all architectonic material cultures in circulation through the tenth and eleventh centuries, it does serve to neatly illustrate in a single object the rich and varied interplays of form, ornament, scale, and substance that constituted the meshwork envisaged in this study. Moreover, with the Bayeux Tapestry we find an architectonic meshwork woven into a commemorative context, providing a contrast to hogbacks where we are instead confronting a meshwork of citations but distilled into the solid space of carved stone.

The significance of this argument is that it cross-cuts conventional Norse/native, pagan/Christian dichotomies and refuses to frame the interpretation of carved stone monuments in these terms. This discussion identifies no single source of inspiration for the internally diverse and innovative monuments known as hogbacks. Indeed, the study unashamedly takes an international perspective, exploring stones in relation to not only their immediate districts, but to far-flung materials and ideas. It considers parallels between hogbacks and objects usually found far outside their orbit from around the Irish and North Sea worlds and artefacts and structures also found on the Continent and in Scandinavia. In doing so, it suggests that the hogbacks' character and variability requires the perspective of long distance communications linking ecclesiastical sites and the secular communities they served, and requires us not to restrict our perspective to those artefacts demonstrably proven to have widely circulated in northern England and southern Scotland.

This perspective allows the study to focus on the commemorative efficacy of hogbacks within a multi-scale, multimedia network of citation linking architectures, monuments, and artefacts known across a broad stretch of time and space. It should also be noted that, given the strong possibility that hogbacks were originally vividly painted, the allusions and associations with these other media (including metalwork) would have been even more 
apparent than might appear at first glance in their current bare, worn, and often fragmented condition. This discussion emphasizes the mutability of stone grave covers and helps us appreciate their varied designs and deployment. In particular, exploring the 'material world' of hogbacks helps us to reconsider why they have a particular regional distribution in the middle of the island of Britain: a region participating in complex and far flung exchange networks spanning the Irish Sea and North Sea zones of interaction and located in the area of the former kingdom of Northumbria and its British and southern Pictish neighbours. It was in this area that political and ecclesiastical disruption, as much as Scandinavian immigration, created a climate in which the body's protection and commemoration in death became a focus of material attention.

The hogbacks' commemorative power was therefore not only achieved through the miniaturizing of churches and halls, thus condensing architectures into a mortuary space, but also by referencing a range of furnishings, structures, and containers which protected all manner of treasures and artefacts. These artefacts were key to binding together Vikingage societies socially and economically.

The Viking Age in northern Britain was clearly a world in which a myriad different architectonic and beast-guarded containers circulated, were displayed, and consigned in mortuary environments. By citing, and enhancing this material world in different fashions, specific recumbent stone monuments constituted and protected tombs configured as architecture framed by beasts, offering security but also promising intersession between the living and the dead.

\section{ACKNOWLEDGEMENTS}

I am very grateful for the invaluable and critical comments of Ing-Marie Back Danielsson, Marianne Hem Eriksen, Leszek Gardeła, Alison Klevnäs, Ruth Nugent, and Patricia Murrieta-Flores. For guidance on images, I would like to thank Derek Craig, Doreen Newcombe, and Fredrik Svanberg. I am grateful to the Corpus of Anglo-Saxon Stone Sculpture for granting permissions to reproduce images. All errors remain my responsibility. The research leading to these results has received funding from the European Research Council under the European Union's Seventh Framework Programme (FP/2007-2013)/ERC Grant Agreement n. 284085.

\section{References}

Primary Sources

Colgrave, B. \& Mynors, R.A.B., ed. 1979. Bede's Ecclesiastical History of the English People. Oxford: Clarendon Press.

Bradley, S. trans. 1982. Anglo-Saxon Poetry. London: Dent.

Larrington, C. trans. 1996. The Poetic Edda. Oxford: Oxford University Press. 
Arwidsson, G. \& Berg, G. 1999. The Mästermyr Find: A Viking Age Tool Chest from Gotland. Stockholm: Larson.

Ashby, S. 2014. A Viking Way of Life. Stroud: Amberley.

Ashby, S. 2015. What Really Caused the Viking Age? The Social Content of Raiding and Exploration. Archaeological Dialogues, 22:89-106.

Back Danielsson, I.-M. 2007. Masking Moments: The Transition of Bodies and Beings in Late Iron Age Scandinavia. Stockholm Studies in Archaeology 40. Stockholm: Stockholm University.

Back Danielsson, I.-M. 2015. The Social Qualia of kuml. An Exploration of the Iconicity of Rune-stones with Kuml Inscriptions from the Scandinavian Late Viking Age. Current Swedish Archaeology, 23:73-94.

Bailey, R. 1980. Viking Age Sculpture in Northern England. London: Collins.

Bailey, R. 2010. Corpus of Anglo-Saxon Stone Sculpture Volume IX: Cheshire and Lancashire. Oxford: Oxford University Press.

Bailey, R. \& Cramp, R. 1988. Corpus of Anglo-Saxon Stone Sculpture Volume II: Cumberland, Westmorland and Lancashire North-of-the-Sands. Oxford: Oxford University Press.

Batey, C. \& Graham-Campbell, J. 1998. Vikings in Scotland: An Archaeological Survey. Edinburgh: Edinburgh University Press.

Boddington, A. 1996. Raunds Furnells: The Anglo-Saxon Church and Churchyard. London: English Heritage.

Brønsted, J. 1936. Danish Inhumation Graves of the Viking Age: A Survey. Acta Archaeologica, 7:81-228.

Brookes, S. 2007. Boat-Rivets in Graves in Pre-Viking Kent: Reassessing Anglo-Saxon BoatBurial Traditions. Medieval Archaeology, 51: 1-18.

Brown, P. 1981. The Cult of Saints. Its Rise and Function in Latin Christianity. Chicago: University of Chicago Press.

Carroll, J., Harrison, S.H. \& Williams, G., eds. 2014. The Vikings in Britain and Ireland. London: Thames \& Hudson.

Christiansen, T. 2007. A New Round of Excavations at Lejre (to 2005). In: J.D. Niles, ed. Beowulf and Lejre. Tempe (AZ): Arizona Center for Medieval and Renaissance Studies, pp. 109-26. 
Coatsworth, E. 2008. Corpus of Anglo-Saxon Stone Sculpture Volume VIII: Western Yorkshire. Oxford: Oxford University Press.

Collingwood, W.G. 1927. Northumbrian Crosses of the Pre-Norman Age. London: Faber \& Faber.

Craig-Atkins, E. 2012. Chest Burial: A Middle Anglo-Saxon Funerary Rite from Northern England. Oxford Journal of Archaeology, 31: 317-37.

Cramp, R. 1984a. Grammar of Anglo-Saxon Ornament. A General Introduction to the Corpus of Anglo-Saxon Stone Sculpture. Oxford: Oxford University Press.

Cramp, R. 1984b. Corpus of Anglo-Saxon Stone Sculpture Volume I: County Durham and Northumberland, 2 Volumes. Oxford: Oxford University Press.

Dobat, A. 2006. Bridging Mythology and Belief. Viking Age Functional Culture as a Reflection of the Belief in Divine Intervention. In: A. Andrén, K. Jennbert \& C. Raudvere, eds. Old Norse Religion in Long-term Perspectives. Origins, Changes, and Interactions. Lund: Nordic Academic Press, pp. 184-88.

Edwards, N. \& Gray Hulse, T. 1992. A Fragment of a Reliquary Casket from Gwytherin, North Wales. The Antiquaries Journal, 72:91-101.

Eriksen, M.H. 2013. Doors to the Dead. The Power of Doorways and Thresholds in Viking Age Scandinavia. Archaeological Dialogues, 20:187-214.

Eriksen, M.H. 2016. Commemorating Dwelling. The Death and Burial of Houses in Iron and Viking Age Scandinavia. European Journal of Archaeology, 19.3.

Gansum, T. 2003. Hår og stil og stilig hår. Om langhårets maktsymbolikk. In: F. Stylegar \& P. Rolfsen, eds. Snartemofunnene i nytt lys (Oldsaksamlingens skrifter 2). Oslo: Universitetets kulturhistoriske museer, pp. 191-220.

Gardeła, L. 2008. Into Viking Minds: Reinterpreting the Staffs of Sorcery and Unravelling Seiðr. Viking and Medieval Scandinavia, 4:45-84.

Gardeła, L. 2009. A Biography of the Seiðr-Staffs. Towards an Archaeology of Emotions. In: L.P. Słupecki \& J. Morwiec, eds. Between Paganism and Christianity in the North. Rzeszów: Wydawnictwo Uniwersytetu Rzeszowskiego, pp. 190-219.

Gardeła, L. 2012. Entangled Worlds. Archaeologies of Ambivalence in the Viking Age, 2 Volumes. PhD dissertation, University of Aberdeen. [accessed 25 March 2016]. Available at http://digitool. abdn.ac.uk/webclient/StreamGate?fol der_id=o\&dvs=1458895998338_355. 
Gardeła, L. 2013. Dead or Alive? - 'Chamber Graves' and Their Inhabitants in the Old Norse Literature and Viking-Age Archaeology. In: S. Moździoch, B. Stanisławski \& P. Wiszewski, eds. Scandinavian Culture in Medieval Poland. Wrocław: Institute of

Archaeology and Ethnology of the Polish Academy of Sciences, pp. 373-93.

Graham-Campbell, J. 1998. A Viking-Age Harness-Bow Fragment from Cliffe, N. Yorkshire. Medieval Archaeology, 42:102-3.

Graham-Campbell, J. 2013. Viking Art. London: Thames \& Hudson.

Griffiths, D. 2010. Vikings of the Irish Sea. Stroud: The History Press.

Gustin, I. 2010. Of Rods and Roles. Three Women in Birka's Chamber Graves. In: C. Dobiat \& K. Leidorf, eds. Zwischen Fjorden und Steppe: Festschrift für Johan Callmer zum 65.

Geburtstag (Internationale Archäologie. Studies honoraria, 31). Rahden: Marie Leidorf, pp. 342-54.

Hadley, D. 2006. The Vikings in England: Settlement, Society and Culture. Manchester: Manchester University Press.

Hadley, D. 2008. Warriors, Heroes and Companions: Negotiating Masculinity in Viking-Age England. In: S. Crawford \& H. Hamerow, eds. Anglo-Saxon Studies in Archaeology and History, 15. Oxford: Oxford University School of Archaeology, pp. 270-84.

Hall, M. 2015. The Meigle Stones: A Biographical Overview. Northern Studies, 46:15-46.

Hall, R. 2007. Exploring the World of the Vikings. London: Thames \& Hudson.

Harrison, S.H. \& Ó Floinn, R. 2014. Viking Graves and Grave-Goods in Ireland (Medieval Dublin Excavations 1962-81 Ser. B. vol. 11). Dublin: National Museum of Ireland.

Hawkes, J. 2002. The Sandbach Crosses. Sign and Significance in Anglo-Saxon Sculpture. London: English Heritage.

Hawkes, J. 2003. Reading Stone. In: C.E. Karkov \& F. Orton, eds. Theorizing AngloSaxon Stone Sculpture. Morgantown (WV): West Virginia University Press, pp. 5-30.

Henderson, G. \& Henderson, I. 2004. The Art of the Picts: Sculpture and Metalwork in Early Medieval Scotland. London: Thames \& Hudson.

Herschend, F. 1997. Livet i hallen. Tre fallstudier I den yngre järnålderns aristokrati (Occasional Papers in Archaeology, 14). Uppsala: Department of Archaeology and Ancient History, Uppsala University. 
Ingold, T. 2007. Writing Texts, Reading Materials. A Response to my Critics.

Archaeological Dialogues, 14:31-38.

Jesch, J. 2015. The Viking Diaspora. London: Routledge.

Jones, A. 2007. Memory and Material Culture. Cambridge: Cambridge

University Press.

Jørgensen, L. 2003. Manor and Market at Lake Tissø in the Sixth to Eleventh Centuries: The Danish 'Productive Sites'. In: T. Pestell \& K. Ulmschneider, eds. Markets in Early Medieval Europe: Trading and Productive Sites. Macclesfield: Windgather, pp. 175-207.

Kershaw, J.F. 2009. Culture and Gender in the Danelaw: Scandinavian and AngloScandinavian Brooches. Viking and Medieval Scandinavia, 5:295-325.

Klevnäs, A. 2016. 'Imbued with the Essence of the Owner': Personhood and Possessions in the Reopening and Reworking of Viking Age Burials. European Journal of Archaeology, 19.3.

Kopár, L. 2012. Gods and Settlers. The Iconography of Norse Mythology in AngloScandinavian Sculpture. Turnhout: Brepols.

Lang, J. 1972-4. Hogback Monuments in Scotland. Proceedings of the Society ofAntiquaries of Scotland, 105:206-35.

Lang, J. 1976. Sigurd and Weland in re-Conquest Carving from Northern England. Yorkshire Archaeological Journal, 48:83-94.

Lang, J. 1984. The Hogback: A Viking Colonial Monument. In: S.C. Hawkes, J. Campbell \& D. Brown, eds. Anglo-Saxon Studies in Archaeology and History, 3. Oxford: Oxford University Committee for Archaeology, pp. 83-176.

Lang, J. 1991. Corpus of Anglo-Saxon Stone Sculpture Volume III: York and Eastern Yorkshire. Oxford: Oxford University Press.

Lang, J. 1994. The Govan Hogbacks: A Reappraisal. In: A. Richie, ed. Govan and Its Early Medieval Sculpture. Stroud: Sutton, pp. 123-32.

Lang, J. 2001. Corpus of Anglo-Saxon Stone Sculpture Volume VI: Northern Yorkshire. Oxford: Oxford University Press.

Larsson, L. 2010. Memories of Features, Memories in Finds. The Remembrance of the Past in Iron Age Scandinavia. In: K.T. Lillios \& V. Tsamis, eds. Material Mnemonics: Everyday Memory in Prehistoric Europe. Oxford: Oxbow, pp. 174-87.

Lund, J. \& Arwill-Nordbladh, E. 2016. Material Citations: Diverging Ways of Relating to the Past in the Viking Age. European Journal of Archaeology, 19.3. 
Mikkelsen, P., Moltsen, A.S.A. \& Sindbæk, S.M. 2008. Tæbring, NW Denmark, AD 600-1100, an Archaeological and Archaeobotanic Study. Acta Archaeologica, 79: 79-109.

Ní Ghrádaigh, J. \& Mullins, J. 2013. Apostolically Inscribed: St Cuthbert's Coffin as Sacred Vessel. In: J. Ashbee \& J. Luxford, eds. Medieval Art and Architecture in Newcastle and Northumberland (British Archaeological Association Transactions Series, 36). Leeds: Maney, pp. 73-89.

Pierce, I. 2002. Swords of the Viking Age. Woodbridge: Boydell.

Price, N. 2002. The Viking Way: Religion and War in Late Iron Age Scandinavia. Uppsala: Department of Archaeology and Ancient History, Uppsala University.

Price, N. 2010. Passing into Poetry: Viking-Age Mortuary Drama and the Origins of Norse Mythology. Medieval Archaeology, 54:123-56.

Price, N. 2015. From Ginnungagap to the Ragnarök, Archaeologies of the Viking Worlds. In: M.H. Eriksen, U. Pedersen, B. Rundkberget, I. Axelsen \& H.L. Berg, eds. Viking Worlds. Things, Spaces and Movement. Oxford: Oxbow, pp. 1-9.

Richards, J.D. 1991. Viking Age England. Stroud: Tempus.

Richards, J.D. 2011. Anglo-Scandinavia Identity. In: H. Hamerow, D.A. Hinton \& S. Crawford, eds. The Oxford Handbook of Anglo-Saxon Archaeology. Oxford: Oxford University Press, pp. 46-61.

Rodwell, W., Hawkes, J., Howe, E. \& Cramp, R. 2008. The Lichfield Angel: A Spectacular Anglo-Saxon Painted Sculpture. The Antiquaries Journal, 88:48-108.

Schmidt, H. 1973. The Trelleborg House Reconsidered. Medieval Archaeology, 17:52-77.

Schmidt, H. 2007. Reconstruction of the Lejre Hall. In: J.D. Niles, ed. Beowulf and Lejre. Tempe (AZ): Arizona Center for Medieval and Renaissance Studies, pp. 103-8.

Sherlock, S. 2012. A Royal Anglo-Saxon Cemetery at Street House, Loftus North-East Yorkshire (Tees Archaeology Monograph Series, 6). Hartlepool: Tees Archaeology.

Sikora, M. 2010. The Finglas Burial: Archaeology and Ethnicity in Viking-Age Dublin. In: J. Sheehan \& D. Ó Corráin, eds. The Viking Age: Ireland and the West. Papers from the Proceedings of the Fifteenth Viking Congress, Cork, 18-27 August 2005. Dublin: Four Courts Press, pp. 402-29.

Sindbæk, S. 2007. The Small World of the Vikings: Networks in Early Medieval Communication and Exchange. Norwegian Archaeological Review, 40:59-74. 
Staecker, J. 2006. Heroes, Kings, and Gods. Discovering Sagas on Gotlandic Picture-Stones. In: A. Andrén, K. Jennbert \& C. Raudvere, eds. Old Norse Religion in Long-Term Perspectives. Origins, Changes, and Interactions. Lund: Nordic Academic Press, pp. 363-68.

Stocker, D. 2000. Monuments and Merchants: Irregularities in the Distribution of Stone Sculpture in Lincolnshire and Yorkshire in the Tenth Century. In: D.M. Hadley \& J. D. Richards, eds. Cultures in Contact: Scandinavian Settlement in England in the Ninth and Tenth Centuries. Turnhout: Brepols, pp. 179-212.

Stylegar, F.-A. \& Grimm, O. 2005. Boathouses in Northern Europe and the North Atlantic. International Journal of Nautical Archaeology, 34: 253-68.

Svanberg, F. 2003. Death Rituals in South-East Scandinavia AD 800-1000. Decolonizing the Viking Age 2. Stockholm: Almqvist \& Wiksell International.

Thäte, E. 2007. Monuments and Minds: Monument Re-use in Scandinavia in the Second Half of the First Millennium AD (Acta Archaeologica Lundensia Series in $4^{\circ}, 27$ ). Lund:

Department of Archaeology and Ancient History, University of Lund.

Thompson, V. 2003. Memory, Salvation and Ambiguity: A Consideration of some AngloScandinavian Grave-Stones from York. In: H. Williams, ed. Archaeologies of Remembrance: Death and Memory in Past Societies. New York: Kluwer, pp. 215-26.

Thompson, V. 2004. Dying and Death in Later Anglo-Saxon England. Woodbridge: Boydell.

Tweddle, D., Biddle, M. \& Kjølbye-Biddle, B. 1995. Corpus of Anglo-Saxon Stone Sculpture Volume IV: South-East England. Oxford: Oxford University Press.

Webster, L. 2011. Anglo-Saxon Art. London: British Museum.

Williams, H. 2006. Death and Memory in Early Medieval Britain. Cambridge: Cambridge University Press.

Williams, H. 2013. Death, Memory and Material Culture: Catalytic Commemoration and the Cremated Dead. In: S. Tarlow \& L. Nilsson Stutz, eds. The Oxford Handbook of the Archaeology of Death and Burial. Oxford: Oxford University Press, pp. 195-208.

Williams, H. 2014. Memory Through Monuments: Movement and Temporality in Skamby's Boat Graves. In: H. Alexandersson, A. Andreeff \& A. Bünz, eds. Med hjärta och hjärna. En vänbok till professor Elisabeth Arwill-Nordbladh (GOTARC Series A, Gothenburg Archaeological Studies, 5). Göteborg: Göteborgs Universitet, Institutionen för historiska studier, pp. 397-414.

Williams, H. 2015. Hogbacks: The Materiality of Solid Spaces. In: H. Williams, J. Kirton \& M. Gondek, eds. Early Medieval Stone Monuments: Materiality, Biography, Landscape. Woodbridge: Boydell \& Brewer, pp. 241-68. 
Williams, H. 2016. 'Clumsy and Illogical'? Reconsidering the West Kirby Hogback. The Antiquaries Journal, 96.

Williams, H., Kirton, J. \& Gondek, M. 2015. Introduction: The Materialities, Biographies and Landscapes of Early Medieval Stone Monuments. In: H. Williams, J. Kirton \& M. Gondek, eds. Early Medieval Stone Monuments: Materiality, Biography, Landscape. Woodbridge: Boydell \& Brewer, pp. 1-34.

Youngs, S., ed. 1989. 'The Words of Angels': Masterpieces of Celtic Metalwork, 6th-9 ${ }^{\text {th }}$ Centuries $A D$. London: British Museum 